\title{
RESEARCH ON THE INFLUENCE OF MOOC ON INNOVATION AND ENTREPRENEURSHIP EDUCATION IN UNIVERSITIES
}

\author{
Yu GuangHua*, Wang ShanQi, Wang XiaoYan \\ Computer Science and Information Engineering, Heihe University, Heihe 164300, China \\ *Corresponding Author E-mail: ygh2862@163.com
}

This is an open access article distributed under the Creative Commons Attribution License, which permits unrestricted use, distribution, and reproduction in any medium, provided the original work is properly cited

\section{ARTICLE DETAILS}

\section{Article History:}

Received 12 November 2017 Accepted 12 December 2017 Available online 1 January 2018

\section{ABSTRACT}

\begin{abstract}
Mooc is a new mode of learning and education. It's an important reform and perfection to the traditional teaching mode. This essay has researched and summarized the feature of Mooc, which has introduced the development situation of Mooc in our country. It puts forward many advantages of Moocs on the basis of analyzing the disadvantages of University innovation and entrepreneurship education deeply. It makes up the contradictions such as imperfection of curriculum system setting and teachers strength weak in innovation and entrepreneurship education of Chinese universities. Mooc can strengthen the rationality of innovation and entrepreneurship effectively in Universities and put forward some pertinent suggestions.
\end{abstract}

\section{KEYWORDS}

Mooc, innovation entrepreneurship.

\section{INTRODUCTION}

Since 2012, Mooc has developed with irresistible force, which brings a great impact to the traditional education. The development form of Mooc is worth pondering to teaching stuff. Furthermore, with the rapid development of China's economy, it is a continuous difficult employment problem in universities. Making a comprehensive survey on developed countries such as the United States, it did not appear that the employment of college students is difficult employment of undergraduates with the development of economy. Behind the development of form, the reason largely is the ability of college students cannot meet the speed of highspeed economic development. A new requirement was put forward to our talents training in high education, but appearance of Mooc has promoted the innovation of talent training mode, and it injects new train of thoughts to our country's innovation and entrepreneurship education.

\section{MOOC'S CHARACTERISTICS}

Mooc is a massive online course, it's a change in the mode of higher education driven by information technology such as the Internet and big data analysis. It can share high-quality educational resources in the world and be enable to select high-quality learning resources for learners to keep abreast of the times. Therefore, the correct understanding of the Mooc education essence and the complementary with advantages of traditional education will improve the quality of education.

At the same time, we should pay special attention to the fact that Mooc is different from the traditional network courses. The network video open classes provide curriculum resources only and does not organize teaching and learning feedback system. It does not have a complete syllabus, the most important is that no links consist between students and teachers and between students and students. To Mooc, it has an independent and complete teaching program and discusses with students to establish a feedback mechanism. By learning from Mooc, learners can discuss, complete their homework, take exams and get their degree certificates according to their own needs. Mooc is a complete learning process and it has systematisms which network video open classes possess. Mooc selects the excellent courses from the well-known universities which were explained by experts or teams. The time of Mooc are not long, and the courses forms are various, through the interaction between learning and teacher, teachers can send up-to-date knowledge to students and grasp the students' understanding of the situation at any time.

\section{DEVELOPMENT OF MOOC IN CHINA}

Since 2013, Mooc has swept the market of higher education in China on a large-scale, In the Courser a platform, 130 thousand Chinese users registered about a year, the number ranked ninth in the world. After 2014, the number of Chinese users has update to 65 thousand, the growth rate of the number of Chinese users is exceed other countries. Based on a study seen from this date, our individual learning style is the same as the concept of creation of Mooc [1]. And since 1930s, with the development of information and network technology, the third generation of Modern Distance Education based on the information technology and network technology has appeared in China with the development the development of information and network technology. Further development of Internet+ and big data technology can lead the development of Mooc and it can bring an innovative side to our higher education [2].

\section{PROBLEMS OF INNOVATION AND ENTREPRENEURSHIP EDUCATION EXISTINGIN CHINESE UNIVERSITIES}

4.1 Innovation and entrepreneurship teaching system should be improved

Opinions of the general office of the State Council on deepening the reform of innovation and entrepreneurship education in Institutions of higher learning has issued in May 2015, many universities in China have taken innovation and entrepreneurship as one of the goals of talent training, however, the curriculum system construction, the form of education and teaching and the strength of teachers are not perfect enough [3]. All these factors lead some results such as lacking cultivation of positive innovation thinking, lacking understanding of the knowledge, lacking innovative ideas, innovation and entrepreneurship in the form and content of education and social needs of a certain distance, the overall quality of education is not high, the effect is not obvious. 


\subsection{Teachers are weak, and the curriculum system is out of order}

Teachers need to be strengthened. Teacher is the organizer and manager of innovation and entrepreneurship education, and the main force of theoretical research, is also the builder and practitioner of the curriculum system of innovation and entrepreneurship education. He plays an important role in the innovation and entrepreneurship education system. However, the innovation and entrepreneurship education in China came from the college students in growing employment pressure, and it started late. Innovation and entrepreneurship related to many disciplines, many fields should have a strong technical factor. This requires teachers have application ability across disciplines first, which makes the innovation and entrepreneurship education of college teachers cannot adapt to the rapid development of innovation and entrepreneurship education in China, this problem has become a bottleneck restricting innovation and entrepreneurship education. Facing this problem, the training of the backbone teachers of innovation and entrepreneurship education is obviously inadequate. Take BUAA for example, it held three training courses of entrepreneurship education teachers, the total numbers have not reach a tenth of the total. Qualified teachers through entrepreneurship education are rare, and teachers engaged in entrepreneurship education are scarce. ${ }^{[3]}$ Second, the overall level of teachers is limited that cannot effectively guide students to carry out innovation and entrepreneurship education. At present, most of the innovative and pioneering teachers in universities teach students with books, and stay in the theoretical, they are lacking practical experience, and do not have entrepreneurial and investment experience. Take Heihe University for example, since 2010 the university at the undergraduate level opened TRIZ theoretical courses, trained tens of thousands of students, but the real students user of TRIZ theory of entrepreneurship are very little, even some students think that this course is not essential. The emergence of this phenomenon in part stem from the teachers who teach innovative course are lacking combination of theory and practice, they only can read the script and talk, and professional knowledge can't be learned through them. The independent teaching of other specialized courses lacks the cultivation of innovative ideas. Therefore, the level of teachers has seriously affected the quality of innovation and entrepreneurship education.

\subsection{The curriculum system needs to be improved}

Innovation and entrepreneurship education is professional education which to impart knowledge innovation, to foster entrepreneurship, to improve innovation ability as the main content, it permeates all aspects of college education. Innovation and entrepreneurship education not only help alleviate the employment pressure of college students, but also help to enhance the innovative ability of college students and deepen the reform of higher education. But now many universities recognize the innovation and entrepreneurship education concept not enough, they think entrepreneurship education is an educational content for employment guidance, mainly on talking policy, analyzing the situation and process of teach entrepreneurship education. The teachers teach this course are the department counselor teachers. Some universities simply believe that entrepreneurship education is to train entrepreneurs, they are keen to hold business talks, business plan competition, set up sales commodity in business center. It makes the enterprise education with obvious utilitarianism tendency. The emergence of these problems shows that the content of innovation and entrepreneurship education in China is not reasonable enough. It pays attention to the theoretical teaching and neglects the practice. It curbs the creativity of students to a certain extent. Secondly, entrepreneurship education is not scientific, China's talent cultivation mode is rigid and not conducive to the development of entrepreneurship education. Based on a study, many universities bring entrepreneurship education into employment education, it is organized by the employment center, Youth League Committee, Student Affairs Office and other departments to conduct entrepreneurship education training which lead the dismounting of entrepreneurship education and subject education, professional knowledge learning and leaving entrepreneurship education out of the talent training program [4].

\subsection{Lacking cohesion on innovation, entrepreneurship, cultivation and national policy}

In recent years, with the innovation of China's universities entrepreneurship education policy launched, the platform for college students as the representative of the University Science and Technology Park has mushroomed. Up to December2014, 134 universities in Jiangsu province have set up and identified 37 science parks at universities above the provincial level. Among them, there are 15 National University Science Parks, rank the first number in the country. According to research, these innovation and entrepreneurial platform for college students provide simplified approval procedures, tax relief and subsidized loans and other preferential policies [5]. But in the specific implementation of the policy, there are some problems. It has not formed a perfect support system for college students' entrepreneurship. For example, policy of entrepreneurship fostering and supporting is not reasonable, the university students evaluate it low.

Hong Jian was found in a survey of Zhejiang university students' innovation and entrepreneurship support system. Only $10.8 \%$ of the students who know and know very well about the policy of entrepreneurship support. The main way to understand the innovation and entrepreneurship policy of college students is only $37.68 \%$ through teachers or students. Therefore, there is no reasonable connection between innovation and entrepreneurship support policy in China and education [6]. In addition, it is rarely involved entrepreneurship process in innovation and entrepreneurship courses, the courses offered make current student entrepreneurship out of touch with current national policy.

\section{MOOC BRINGS NEW VITALITY TO INNOVATION AND ENTREPRENEURSHIP EDUCATION}

MOOC is a new type of network learning style, which shows large-scale, open, personalized and interactive features compared with the traditional classroom learning methods or other online courses. It brings the experience and wisdom of innovation and education masters at home and abroad, through the network and students to share innovation and entrepreneurship courses and experience to build a dream stage for college students. At the same time, through MOOC allows many entrepreneurs and college students to intimate interaction so that students have more opportunities to participate in the practice of the project and thus enhance innovation ability. By participating in MOOC speaker line exchanges can process more experienced business horizons. Through MOOC interaction and thinking collision in the class to stimulate the engineering college students' inspiration for innovation and entrepreneurship.

The advantages of MOOC fill the curriculum system of entrepreneurship education in universities innovation unreasonable and teacher's shortage contradiction in China. Because of the cloud computing technology, networking, modern encryption algorithm, Fab Lab, IAAS, PASS and other information technology development, it make MOOC platform of innovative and entrepreneurship education more secure and efficient, it can provide information technology services for schools and teachers, integrate educational resources, scientific research and teaching, and realize Internet cooperation. Through the construction of innovation and entrepreneurship MOOC platform, we develop virtual simulation practice so that students can complete innovative practice in the open experimental state, it is easy to supervise, management and guidance, and enhance the effect of education. In addition, college teachers can also improve their own quality through MOOC platform, and universities can build their own personalized teaching environment to achieve effective teaching. Students can use MOOC platform, simply through the PC, mobile phones and other equipment to access the network, you can at any time, place, access to educational resources in real time and enjoy educational services. Building MOOC platform of innovation and entrepreneurship teaching, on the base of the big data constructing large-scale sharing of educational resources, it can promote the quality and efficiency of innovation and entrepreneurship education in university.

\section{ACKNOWLEDGMENTS}

Fund project : Philosophy and social science research program project of Heilongjiang province(16EDC04); higher education society "13th five plan" higher education scientific research project of Heilongjiang province(16G369);Higher education teaching reform school-level project(Xjg1529).

\section{ABOUT THE AUTHORS}

YuGuanghua (1984) Heihe city heilongjiang province, Lecturer, Main research direction: Computer process control, innovation and entrepreneurship education. E-mail: ygh2862 @163.com 


\section{REFERENCES}

[1] 2018. http://baike.baidu.com (in Chinese)

[2] Dong, J. 2015. The impact of Moocs and China's higher education. Master's thesis. Shandong Normal University, 6

[3] Yu, G,H., Wang, S.Y. 2017. The research on talent training mode in local engineering colleges under the background of innovation and Entrepreneurship[J]. Education teaching Forum, (32), 30-31

[4] Jiang, D.Q. 2011. The construction of education teaching team for university innovation and entrepreneurship. China Higher Education, (10), 34

[5] Lin, Y.L., Zeng, C. 2015. Analysis and construction of education innovation and entrepreneurship in colleges and universities. Heilongjiang high education research, 5

[6] Hong. 2013. The investigation and thinking of innovation and entrepreneurship support system for university students in zhejiang province. Zhejiang social sciences, (5), 141. 